\title{
Rancangan Model Pemberdayaan Pelaku UKM Dalam Upaya Penanggulangan Kemiskinan Dengan Berbasis Zakat Produktif (Studi Kasus Implementasi Program Jatim Makmur Dari Badan Amil Zakat Nasional Provinsi Jawa Timur di Kelurahan Embong Kaliasin Surabaya)
}

\author{
Arief Setiawan ${ }^{1}$, Darsono Wisadirana ${ }^{2}$, Sholih $\mathrm{Mu}^{\prime}$ adi $^{3}$ \\ ${ }^{1}$ Mahasiswa Program Pascasarjana, FISIP, UB \\ ${ }^{2}$ Dosen Program Pascasarjana, FISIP, UB \\ ${ }^{3}$ Dosen Program pascasarjana, FISIP, UB.
}

\begin{abstract}
Abstrak
Berdasarkan penelitian Badan Amil Zakat Nasional dan Institut Pertanian Bogor pada tahun 2012 potensi Zakat di Indonesia sebesar 217 triliun, khusus untuk Jawa Timur saja sebesar 15 triliun, tentu saja nilai sebesar itu sangat potensial dalam membantu program penanggulangan kemiskinan. Salah satu elemen masyarakat yang bisa diberdayakan dengan dana zakat produktif adalah para pelaku Usaha Kecil Menengah yang seringkali mengalami kesulitan dalam modal usaha. Penelitian ini menggunakan teori modal sosial dan pemberdayaan masyarakat sebagai alat analisanya, sedangkan jenis penelitiannya berjenis deskriptif kualitatif dengan metode studi kasus. Kesimpulan yang dapat diambil dalam penelitian ini adalah : 1) Dalam pengumpulan zakat ada tiga cara yang bisa dilakukan, yaitu muzakki/donatur datang setor langsung ke Badan Amil Zakat Nasional Provinsi Jawa Timur atau transfer ke rekening Badan Amil Zakat Nasional Provinsi Jawa Timur, diambil petugas juru pungut ke rumah/alamat muzakki, dan yang terakhir yaitu dikumpulkan melalui bendahara gaji atau Unit Pengumpul Zakat di masing-masing instansi kerjanya. 2) Secara umum implikasi penyaluran zakat produktif dalam bentuk bantuan modal bergulir terhadap peningkatan keadaan ekonomi pelaku Usaha Kecil Menengah di lokasi penelitian cenderung cukup baik, tergantung bagaimana kreatifitas individu yang mengelolanya. 3) Dalam perancangan model pemberdayaan pelaku Usaha Kecil Menengah berbasis zakat produktif diperlukan sinergitas yang kontinyu antara Pemerintah Provinsi Jawa Timur dengan Badan Amil Zakat Nasional Provinsi Jawa Timur.
\end{abstract}

Kata kunci: Kemiskinan, Mustahik, Muzakki, Pemberdayaan, Zakat.

\begin{abstract}
Based on Amil Zakat National Agency and Bogor Agricultural Institute research in 2012, the zakat potential in Indonesia was 217 billion rupiahs in 2012, specifically 15 billion rupiahs in East Java. This what makes it highly potential for the attempts to alleviate the poverty. One of the elements of society that can be empowered with productive Zakat funds are small and medium business actors who often have difficulty in business capital. This research applied a social capital theory and society empowerment as the analysis tools, and used a qualitative descriptive method along with the case study method. In conclusion, 1) there are three ways in collecting zakat i.e. the Muzakki or donors come straightly to BAZ or transfer their funds to the bank account of Amil Zakat National Agency East Java, the fund can be collected by the levy workers to Muzakki's house, and lastly, zakat can be collected through salary-treasures or Zakat Collecting Unit in each institution. 2) Generally, the implication of productive zakat distribution in the forms of flowing capital to the improvement of the small and medium business actors economic conditions in this research's location is considered as to be relatively good, depending on the level of creativity of each individual who runs the business. 3) In designing empowerment model of small and medium business actors based on productive zakat, synergic and continuous cooperation between the Government of East Java Province with Amil Zakat National Agency East Java Province are required.
\end{abstract}

Keywords: Empowerment, Mustahik, Muzakki, Poverty, Zakat.

\section{PENDAHULUAN}

Kemiskinan merupakan masalah dalam pembangunan yang bersifat multidimensional yang berkaitan dengan aspek sosial, ekonomi, budaya, dan aspek lainnya. Kemiskinan ditandai oleh keterisolasian, keterbelakangan,

Alamat Korespondensi Penulis:

Arief Setiawan, S.Kom, M.Sos.

Email : setiawan.bkw@gmail.com

Alamat : : Gubeng Kertajaya 7L / No. 1 Surabaya 60286 dan pengangguran, yang kemudian meningkat menjadi ketimpangan antar daerah, antar sektor, dan antar golongan penduduk. Kemiskinan timbul karena ada sebagian daerah yang belum sepenuhnya tertangani, ada sebagian sektor yang harus menampung tenaga kerja secara berlebihan dengan tingkat produktivitas yang rendah, dan ada pula sebagian masyarakat yang belum ikut serta dalam proses pembangunan sehingga belum dapat menikmati hasilnya secara memadai [1]. 
Indonesia sangat kaya dengan bahan tambang dan minyak bumi, tetapi dalam pengelolaannya Indonesia sangat tidak diuntungkan dengan kekuatan kapitalis yang mempunyai kekuatan strategis terhadap minyak bumi dalam negeri. Indonesia tak lagi memiliki kedaulatan atas energi yang dimilikinya. Indikatornya, migas dalam negeri dikuasai perusahaan asing. Tercatat 160 kontraktor migas menguasai kontrak migas nasional. Ironisnya, 85 persennya produksi minyak mentah dikuasai perusahaan asing. Chevron dan Exxon menguasai hampir separuh produksi migas nasional. Sebagian besar usaha kegiatan hulu migas dikuasai Chevron. Perusahaan asal AS ini menguasai 47 persen produksi migas nasional. Sebesar 37 persennya dikuasai swasta dan asing lainnya. Di mana peran perusahaan nasional? Pertamina hanya menguasai 16 persen saja. Dengan kondisi ini, tentu saja potensi kekayaan minyak nasional tidak lagi dapat dinikmati rakyat. Keuntungan dari sumber daya alam bidang migas dinikmati segelintir perusahaan asing. Anehnya Indonesia juga harus membeli minyak miliknya sendiri dengan harga yang lebih mahal di pasar internasional. Migas diobral murah kepada perusahaan asing menyebabkan produksi nasional rendah, sementara harga semakin tinggi. Akibatnya negara dirugikan pada satu sisi, namun perusahaan minyak diuntungkan pada sisi yang lain [2].

Dari ilustrasi yang telah dikemukakan di atas, segala permasalahan-permasalahan itu timbul karena bangsa Indonesia mengalami krisis percaya diri dan merasa tidak berdaya jika berhadapan dengan negara-negara lain yang memiliki keunggulan di bidang teknologi, permodalan, dan sumber daya manusia. Ketidakberdayaan merupakan suatu keadaan melarat dan ketidakberuntungan, suatu keadaan minus (deprivation), bila dimasukkan dalam konteks tertentu (Indonesia), hal itu berkaitan dengan dengan minimnya sumber daya, pendapatan dan harta, kelemahan fisik, isolasi, kerapuhan, keterbatasan akses, ketiadaan modal, dan kekurangan [3].

Salah satu program dari Pemerintah Provinsi Jawa Timur yang bertujuan untuk menanggulangi masalah kemiskian dan menciptakan kesempatan kerja adalah Program Jalan Lain Menuju Kesejahteraan Bantuan Rumah Tangga Sangat Miskin (Jalin Kesra Bantuan RTSM) yang dilaksanakan mulai tahun 2010 sampai tahun 2013. Dengan program Jalin Kesra, diharapkan status rumah tangga sangat miskin yang ada di Jawa Timur dapat diangkat dan diharapkan nantinya keluarga RTSM tersebut benar-benar mampu keluar dari garis kemiskinan. Dengan demikian Program Jalin Kesra dirancang sebagai program keberpihakan Gubernur Jawa Timur terhadap orang miskin (Pro Poor) yang fokusnya adalah memberikan bantuan terhadap Rumah Tangga Sangat Miskin (RTSM) berupa bantuan uang dan pangan (cash transfer) dan natura produktif [4].

Tetapi pada implementasinya di lapangan banyak permasalahan yang terjadi dalam pelaksanaan program Jalin Kesra. Menurut pengamatan penulis dan sumber berita yang didapat dari internet, permasalahan yang kerap terjadi antara lain [5]:

1. Seringkali penerima bantuan sudah berusia tua sehingga sudah tidak layak lagi dalam mengelola paket bantuan yang diberikan, harusnya beliau menerima bantuan biaya hidup/kesehatan tetapi malah dapat bantuan alat kerja.

2. Spesifikasi paket bantuan yang diserahkan seringkali tidak layak (terutama untuk paket bantuan ternak), ukurannya kecil-kecil dan dalam kondisi yang sakit, sehingga tidak lama setelah diserahkan, ternak tersebut mati.

3. Seringkali paket bantuan yang diberikan tidak sesuai antara barang yang diminta dengan realisasi.

4. Belum pernah dilakukan kegiatan pendampingan atau bimbingan teknis, monitoring atau pengawasan dan evaluasi dari pihak yang terkait, sehingga jika ada masalah dengan paket bantuan tidak ada solusi.

5. Terjadi korupsi oleh penyedia barang/jasa dalam pendistribusian paket bantuan untuk warga miskin di Jawa Timur.

Salah satu sisi ajaran Islam yang belum ditangani secara serius adalah optimalisasi pendayagunaan zakat, infaq dan shadaqoh untuk pengentasan kemiskinan.

Zakat diambil secara vertikal jika telah mencapai nisab, yaitu sebagai ketetapan dengan batasan minimal wajibnya zakat dikeluarkan. Begitu juga dengan ukuran barang yang wajib dikeluarkan pada barang yang wajib dikeluarkan zakatnya. Kelebihan harta yang dimiliki dikeluarkan sesuai ketetapan yang ditentukan oleh ahli fiqih. Sedangkan pembagian zakat dilakukan secara horizontal atau merata pada kelompok yang berhak menerima zakat (mustahik). [6]

Badan Amil Zakat Nasional (BAZNAS) Provinsi Jawa Timur adalah lembaga pengelola zakat milik 
Pemerintah Provinsi Jawa Timur yang mempunyai program pemberdayaan masyarakat miskin dengan pemberian bantuan pinjaman permodalan tanpa bunga bagi para pelaku Usaha Mikro Kecil Menengah (UMKM) di wilayah Jawa Timur disertai dengan pendampingan usaha dan pembinaan mental keagamaan secara berkelompok sehingga para mustahik/pelaku UKM itu bisa menjadi masyarakat yang produktif, mandiri dan tidak tergantung uluran tangan dari orang lain. Di BAZNAS lainnya di 38 Kabupaten/Kota se-Provinsi Jatim belum ada yang mempunyai misi pemberdayaan ekonomi masyarakat, hanya sebatas pada kegiatan perbaikan sektor kesehatan, sosial, dan pendidikan. Kegiatan BAZNAS Kabupaten/Kota hanya pada penyaluran zakat secara konsumtif untuk mencukupi kebutuhan hidup sehari-hari masyarakat miskin/mustahik.

Adapun tujuan dari penelitian ini adalah

1. Mengidentifikasi bagaimana mekanisme pengumpulan dan penyaluran dana zakat dalam bentuk produktif dari BAZNAS Provinsi Jawa Timur.

2. Mengidentifikasi bagaimana implikasi bantuan dana zakat produktif terhadap kegiatan usaha pelaku UKM penerima zakat.

3. Mengidentifikasi, merumuskan dan merancang model pemberdayaan pelaku UKM berbasis zakat produktif dengan pendekatan studi kasus.

\section{METODE PENELITIAN}

Dalam penelitian ini menggunakan metode deskriptif kualitatif dengan pendekatan studi kasus. Lokasi penelitian adalah di BAZNAS Provinsi Jatim sebagai lembaga pengelola zakat dari Pemprov Jatim dan di Kampung Keputran Panjunan yang terletak di Kelurahan Embong Kaliasin Kotamadya Surabaya. Kampung Keputran Panjunan dipilih sebagai salah satu lokasi penelitian karena di daerah tersebut adalah desa binaan BAZNAS Provinsi Jatim, disana terdapat semua program pemberdayaan masyarakat yang dilakukan oleh BAZNAS Provinsi Jatim.

\section{Metode Pengumpulan Data}

Teknik penentuan informan dalam penelitian ini secara Purposive (informan dari BAZNAS Provinsi Jatim, UKM binaan di Keputran Panjunan, pegawai Kelurahan Embong Kaliasin dan masyarakat setempat). Sedangkan untuk pengumpulan datanya yang pertama dengan mengadakan wawancara mendalam (indepth interview) untuk memperoleh data primer dari informan. Yang kedua dengan mengadakan observasi atau pengamatan untuk melengkapi dan cross-check terhadap data yang diperoleh dari wawancara dengan informan di lokasi penelitian. Dan yang ketiga dengan melakukan dokumentasi atau pengumpulan data yang sudah tersusun dalam bentuk dokumen seperti monografi Kelurahan Embong Kaliasin, jumlah keluarga miskin di lokasi penelitian sebagai pendukung argumen dalam penentuan lokasi penelitian, beberapa data pendukung lainnya dari internet seperti kondisi kemiskinan di Indonesia secara umum, data kemiskinan menurut BPS, profil program Jalinkesra oleh Pemprov Jatim, profil BAZNAS Pusat, dan lain sebagainya.

Tabel 1. Jumlah Penerima Bantuan Raskin Di Kelurahan Embong Kaliasin

Sumber : Data Penerima Raskin Kelurahan Embong Kaliasin Tahun 2012 dan 2014.

Dari tabel di atas dapat dijelaskan bahwa jumlah keluarga miskin (Gakin) di kampung Keputran Panjunan berdasarkan jumlah penerima raskin pada tahun 2012 menduduki peringkat tertinggi di kelurahan Embong Kaliasin, tetapi pada tahun 2014 menurun drastis dibanding tahun 2012, hal ini karena PPLS menerapkan regulasi baru bagi penerima bantuan Raskin, dimana yang menerima diprioritaskan kepada kepala keluarga dengan banyak tanggungan

\begin{tabular}{|c|c|c|c|}
\hline No & Nama Kampung/Jalan & $\begin{array}{c}\text { Tahun } \\
2012 \\
\text { (KK) }\end{array}$ & $\begin{array}{c}\text { Tahun } \\
2014 \\
\text { (KK) }\end{array}$ \\
\hline 1 & Embong Blimbing & 4 & 1 \\
\hline 2 & Embong Wungu & 1 & - \\
\hline 3 & Yos Sudarso & 1 & - \\
\hline 4 & Pandegiling & 1 & - \\
\hline 5 & Karang Bulak & 14 & 5 \\
\hline 6 & Lemah Putro & 9 & 3 \\
\hline 7 & Kedondong Lor & 32 & 10 \\
\hline 8 & Rusun Urip Sumoharjo & 50 & 5 \\
\hline 9 & Keputran Panjunan & 410 & 49 \\
\hline 10 & Keputran Pasar Kecil & 182 & 59 \\
\hline 11 & Keputran Kejambon & 253 & 155 \\
\hline 12 & RW 11 RT 002 & - & 1 \\
\hline & Total & 957 & 288 \\
\hline
\end{tabular}

dalam rumah tangga dan penghasilannya dibawah UMR. Sedangkan pada tahun 2012 yang menerima program Raskin adalah kepala keluarga 
dengan banyak tanggungan, para fakir miskin yang sudah lansia dan hidupnya sebatang kara dan tinggal sendirian dirumahnya, serta kepala keluarga yang tidak bekerja (menganggur) dulunya juga dapat bantuan Raskin.

\section{Metode Analisis Data}

Penelitian ini menggunakan pendekatan kualitatif, maka analisa datanya juga menganut cara yang digunakan dalam pendekatan kualitatif. Teknik analisis data interektif yang dikemukakan oleh Miles dan Huberman yang mencakup tiga kegiatan bersamaan yaitu : (1) Reduksi data; (2) Penyajian data; (3) Menarik kesimpulan / Verifikasi. Pada prinsipnya analisis data kualitatif dilakukan bersamaan dengan proses pengumpulan data [7].

\section{HASIL DAN PEMBAHASAN}

Keputran Panjunan adalah suatu kampung perumahan penduduk yang terletak di jantung kota Surabaya, tepatnya masuk wilayah Kelurahan Embong Kaliasin, Kecamatan Genteng. Berdasarkan data raskin tahun 2012 jumlah gakin penerima raskin sebanyak $410 \mathrm{KK}$ dari total $957 \mathrm{KK}$ penerima raskin. Sedangkan pada tahun 2014 jumlah gakin penerima raskin sebanyak $49 \mathrm{KK}$ dari total 288 KK penerima raskin, penurunan jumlah gakin penerima raskin hal karena PPLS menerapkan regulasi baru bagi penerima bantuan raskin, dimana yang menerima diprioritaskan kepada kepala keluarga dengan banyak tanggungan dalam rumah tangga dan penghasilannya dibawah UMR. Sedangkan pada tahun 2012 yang menerima program raskin adalah kepala keluarga dengan banyak tanggungan, para fakir miskin yang sudah lansia dan hidupnya sebatang kara dan tinggal sendirian dirumahnya, serta kepala keluarga yang tidak bekerja (menganggur) dulunya juga dapat bantuan raskin, hal ini tentu cukup menyulitkan petugas kelurahan setempat dalam membagikan raskin karena harus pandai-pandai mengalokasikan pembagian raskin agar tercipta keadilan dan distribusi yang merata bagi gakin penerimanya.

\section{Mekanisme Pengumpulan Dan Penyaluran Zakat Dalam Bentuk Produktif Dari BAZNAS Provinsi Jawa Timur}

Dalam kegiatan BAZ ada 2 kegiatan utama, yaitu kegiatan pengumpulan zakat dan distribusi zakat. Untuk kegiatan pengumpulan yang melaksanakan adalah bidang pengumpulan, sedangkan pada kegiatan distribusi yang melaksanakan adalah bidang distribusi.

\section{Bidang Pengumpulan}

Tugas bidang pengumpulan meliputi sosialisasi zakat sebagaimana terkait dalam undang-undang No. 38 tahun 1999 yang diperbaharui dengan undang-undang No. 23 tahun 2011 sampai pada pembentukan Unit Pengumpul Zakat (UPZ) pada unit-unit kerja pemerintah/BUMD/TNI/POLRI, mengumpulkan dana zakat, infaq, shodaqoh dari unit kerja dan personal serta imbauan kepada masyarakat untuk berzakat dan berinfaq.

Dalam kegiatan pengumpulan zakat ini ada 3 cara yang bisa dilakukan, yaitu :

1. Muzakki/Donatur datang setor langsung ke BAZ atau transfer ke rekening BAZNAS Provinsi Jatim. Untuk transfer zakat ke rekening BAZNAS bisa melalui Bank Syariah Mandiri (No.rekening 7001249724), Bank Jatim (No.rekening 0011183450), dan BNI Syariah (No. Rekening 0707070770).

2. Diambil petugas juru pungut (jungut) ke rumah/alamat Muzakki.

3. Dikumpulkan melalui bendahara gaji atau UPZ (Unit Pengumpul Zakat) di masing-masing instansi kerjanya. Semua SKPD di lingkungan Pemerintah Provinsi Jawa Timur sudah ada UPZ masing-masing (berdasarkan Instruksi Gubernur Jatim No. 1/INST/2010 tentang pembentukan Unit Pengumpul Zakat pada unit kerja Pemerintah Provinsi Jawa Timur), kecuali untuk BUMN-BUMN memang banyak yang belum memiliki UPZ, karena kebijakan dari BUMN tidak sama dengan kebijakan dari Pemprov Jatim.

UPZ pada umumnya beranggotakan 5 orang yang terdiri dari ketua, wakil, sekretaris, bendahara, dan anggota. Dalam pengumpulan zakat oleh UPZ, zakat yang terkumpul $100 \%$ disetorkan ke BAZNAS, tetapi oleh BAZNAS dikembalikan lagi sebanyak $25 \%$ ke masingmasing SKPD dengan tujuan untuk membiayai kegiatan pembinaan dan keagamaan di masing-masing SKPD mereka sendiri. Selain instansi-instansi pemerintah diatas ada juga instansi-instansi swasta yang menyetorkan zakatnya melaui BAZNAS Provinsi Jatim seperti Bank Mandiri, Novotel, Matahari, Ramayana, dan Mercure.

Tabel 2. Realisasi Pengumpulan ZIS Dari Tahun Ke Tahun 
Sumber : Buku Annual Report BAZNAS Jatim Tahun 2013

Dari tabel diatas dapat dijelaskan bahwa ada tren yang menarik, yaitu pada tahun 2010 ke tahun 2011, dan tahun 2011 ke tahun 2012 terdapat kenaikan yang signifikan dalam pengumpulan zakat, hal ini karena zakat mulai masif dikelola oleh lembaga pada tahun 2009 (bersamaan dengan diberlakukannya undangundang no. 38 tahun 1999 tentang pengelolaan zakat), pada tahun 2010-2012 para pengurus

\begin{tabular}{|c|c|c|c|}
\hline No & Tahun & $\begin{array}{c}\text { Target } \\
\text { (Milyar Rupiah) }\end{array}$ & $\begin{array}{c}\text { Realisasi } \\
\text { (Milyar Rupiah) }\end{array}$ \\
\hline 1 & 2010 & - & 3,8 \\
\hline 2 & 2011 & - & 5,1 \\
\hline 3 & 2012 & 6 & 6,47 \\
\hline 4 & 2013 & 6 & 6,5 \\
\hline
\end{tabular}

BAZNAS Provinsi Jatim memaksimalkan sosialisasi zakat ke Pegawai Negeri Sipil di lingkungan Pemprov Jatim dan masyarakat. Sehingga pada kurun waktu itu banyak PNS Pemprov Jatim yang menyampaikan zakatnya ke BAZNAS, sedangkan dari masyarakat belum sebanyak yang dari PNS, hal inilah yang menyebabkan kenaikan zakat pada tahun 2010-2012 meningkat signifikan. Pada tahun 2013 kenaikannya cenderung sedikit karena semua PNS Pemprov Jatim yang pendapatannya sudah mencapai nisabnya sudah menyampaikan zakatnya ke BAZNAS Provinsi Jatim, sosialisasi zakat tetap masih ada tetapi lebih konsentrasi ke masyarakat umum. Diharapkan pada tahun 2014 ini kenaikannya lebih signifikan karena mulai tahun 2013 sudah berlaku UU yang lebih baru tentang pengelolaan zakat yaitu UU No. 23 tahun 2011, yang sudah ada peraturan pemerintah dan peraturan BAZNAS.

\section{Bidang Distribusi/Pendayagunaan}

Sesuai tuntunan syariat Islam dan amanah undang-undang No. 23 tahun 2011, pendistribusian dana zakat, infaq, dan shodaqoh dalam program BAZNAS Jatim menjunjung azas berhasil guna dan berdaya guna. Dari hasil pengumpulan dana zakat, infaq, dan shodaqoh (ZIS) tahun 2013 didistribusikan untuk 5 program utama yaitu : Pendidikan (Jatim Cerdas), Ekonomi (Jatim Makmur), Kesehatan (Jatim Sehat), Sosial (Jatim Peduli), Dakwah (Jatim Taqwa). Berikut ini adalah deskripsi dari 5 program utama [8]:

1. Program Pendidikan/Jatim Cerdas

Program pendistribusian di bidang pendidikan diutamakan pada pemberian beasiswa. Pada awalnya program ini ditujukan kepada siswa
SD, SLTP dan SLTA. Namun pada tahun 2006, seiring dengan adanya bantuan BOS bagi siswa SD dan SLTP dari pemerintah, BAZ lebih berkonsentrasi pada SLTA/MA/Diniyah Ulya dan Mahasiswa. Untuk bantuan beasiswa bagi perguruan tinggi BAZNAS Jatim memiliki program 1 keluarga 1 sarjana, dimana dalam 1 keluarga yang memiliki beberapa orang anak diupayakan minimal ada 1 orang anak yang mengenyam pendidikan di perguruan tinggi.

2. Program Ekonomi/Jatim Makmur

Program pendistribusian bidang ekonomi meliputi kegiatan : pelatihan ketrampilan kerja, bantuan alat kerja serta bantuan modal usaha bergulir. Bantuan modal bergulir dirintis sejak tahun 2006 berupa pemberian bantuan pinjaman permodalan tanpa bunga bagi Usaha Mikro (UMKM) di wilayah Jawa Timur dengan memberikan bantuan permodalan disertai pendampingan usaha serta pembinaan mental keagamaan secara berkelompok.

Dalam penyaluran dana zakat produktif untuk pemberdayaan ekonomi pelaku UKM/mustahik ada 2 bentuk penyaluran yang sebenarnya hampir mirip dan saling terkait erat, yaitu :

- Diberikan kepada mustahik berupa alat kerja bagi mereka yang memiliki ketrampilan akan tetapi tidak memiliki modal untuk membuka usaha.

- Pinjaman modal bergulir untuk UKM dengan membentuk kelompok koperasi dengan anggota sebanyak 10 orang.

3. Program Kesehatan/Jatim Sehat

Program kesehatan yang difokuskan untuk memberikan pelayanan bagi para dhuafa, terbagi atas 2 macam kegiatan yaitu program insidental (pengobatan massal yang tersebar di berbagai daerah miskin dan rawan penyakit), dan program elektif (pembukaan pos pelayanan kesehatan di wilayah pemukiman dhuafa di ketintang, menanggal, keputran dan medokan semampir).

4. Program Sosial/Jatim Peduli

Program sosial yang difokuskan untuk membantu fakir miskin yang terkena musibah. Program ini bersifat santunan berupa bantuan konsumtif. Dibagi menjadi 2 model, yaitu insidental (renovasi rumah dan bantuan bencana alam) dan berkelanjutan/kontinyu (bantuan fakir setiap bulan).

5. Program Dakwah/Jatim Taqwa

Program dakwah diarahkan untuk penguatan keimanan dhuafa dan juga untuk mensosialisasikan zakat di masyarakat dengan 
megirim da'i ke masyarakat, untuk ceramah, khotbah jumat atau safari ramadhan ke instansi-instansi.

\section{Implikasi Program Pendayagunaan Zakat Produktif Terhadap Ekonomi Pelaku UKM}

Untuk mengetahui bagaimana implikasi yang dirasakan oleh pelaku UKM penerima bantuan modal bergulir dari BAZNAS Provinsi Jatim dapat kita ketahui melalui pendapat para pelaku UKM binaan tentang manfaat yang mereka rasakan setelah mendapat bantuan modal bergulir dari BAZNAS Provinsi Jatim tersebut, sampai sejauh mana tingkat perubahan ekonominya dan aset apa saja yang sudah bisa mereka miliki dari hasil usahanya yang semakin berkembang

Dari penuturan ibu-ibu pelaku UKM di Keputran Panjunan pada umumnya mereka merasakan dampak yang sangat positif untuk perbaikan keadaan ekonominya setelah menerima bantuan modal bergulir yang sudah disalurkan oleh BAZNAS Provinsi Jawa Timur melalui program Jatim Makmur. Indikatornya dapat dilihat dari keadaan usahanya yang semakin berkembang dari waktu ke waktu, aset barangbarang rumah tangganya dan alat-alat penunjang kerjanya yang bertambah serta penghasilannya yang berubah dari berpenghasilan tidak tetap menjadi bepenghasilan tetap.

Tabel 3. Data Penyaluran Total Tahun 2013

Sumber : Buku Annual Report BAZNAS Jatim Tahun 2013

Memang tidak semua pelaku UKM yang menerima bantuan modal bergulir dapat merasakan manfaat untuk perbaikan ekonominya, ada 1-2 pelaku UKM yang kondisi ekonominya cenderung stagnan, bahkan sampai bangkrut, tetapi itu bukan karena kesalahan BAZNAS Provinsi Jatim dalam memberikan bantuan modal bergulir dan pendampingan usaha, tetapi karena pelaku UKM tersebut anaknya banyak dan masih kecil-kecil, sedangkan suaminya bekerja sebagai sopir carteran yang nenohasilannya tidak menentu, sehingga bantuan

6 Il bergulir dari BAZNAS Provinsi Jatim hanya cunup untuk mempertahankan toko peracangannya, untuk berkembang lagi masih
Sedangkan bagi pelaku UKM yang bangkrut karena dia mengalami sakit sehingga tidak bisa melakukan pekerjaanya sehari-hari sebagai penjual makanan.

Implikasi zakat yang cukup positif untuk perbaikan ekonomi mustahik tersebut sesuai dengan teori ekonomi yang dikemukakan oleh Irving Fisher melalui persamaannya yaitu $M V=P T$, dimana $\mathrm{M}$ adalah jumlah uang dan $\mathrm{V}$ adalah kecepatan perputaran uang di seluruh perekonomian, $\mathrm{P}$ adalah tingkat harga umum dan $\mathrm{T}$ sama dengan jumlah transaksi yang dilakukan/output selama periode akuntansi tertentu. Dengan meningkatkan jumlah uang (M) kepada mustahik melalui bantuan modal bergulir yang dipakai untuk meningkatkan usahanya dengan menaikkan produktivitas barang yang dihasilkannya maka transaksi yang terjadi (T) dalam kegiatan usaha mustahik akan meningkat, tentu saja ini akan membawa dampak pada stabilitas harga barang yang telah diproduksi oleh mustahik $(P)$, jika produksinya banyak dan lancar maka tingkat harga umum suatu barang akan cenderung stabil, tetapi jika barang itu langka maka harganya juga akan mahal. Jika semua transaksi berjalan dengan lancar dan mobilitas yang tinggi maka kecepatan (V) peredaran uang di masyarakat otomatis juga akan naik pada level yang lebih tinggi dan stabil, tentu saja ini akan berimbas secara positif pada perbaikan ekonomi mustahik menjadi lebih baik [9].

\section{Proses Pemberdayaan Pelaku UKM Di Kampung Keputran Panjunan Surabaya}

Zakat sebagai salah satu built in concept Islam dalam bidang social safety memiliki fungsi untuk menghubungkan potensi dana dari para Muzakki (pemilik harta/orang yang wajib membayar zakat) untuk menangani problem yang dihadapi oleh Mustahik/penerima zakat. Secara garis besar kerangka konsep pemberdayaan dan peningkatan kemandirian mustahik dapat digambarkan melalui diagram berikut ini [10]:

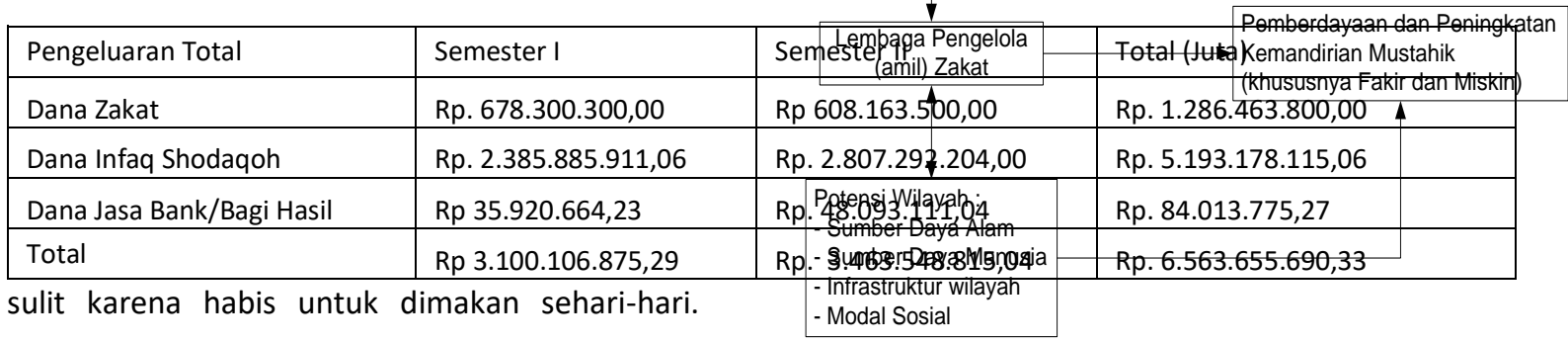


Gambar 1. Kerangka Konsep Pemberdayaan Dan Peningkatan Kemandirian Mustahik

Dari gambar di atas dapat dijelaskan bahwa proses diawali dari muzakki yang membayar/menyalurkan zakatnya melalui lembaga pengelola (amil zakat), dalam proses pengelolaan zakat untuk disalurkan kepada mustahik, lembaga amil zakat sebaiknya memadukan dengan faktor pendukung seperti yang terkandung dalam potensi wilayah mustahik yang bersangkutan, berupa sumber daya alam, sumber daya manusia, infrastruktur wilayah, dan modal sosial. Potensi sumber daya alam merupakan potensi alam yang bisa digunakan untuk meningkatkan kegiatan ekonomi dan meningkatkan pendapatan masyarakat, seperti barang tambang, hutan, minyak bumi, hasil perkebunan, pertanian, dan lain-lain. Sementara itu, potensi infrastruktur wilayah merupakan keberadaan infrastruktur dalam mendukung kegiatan ekonomi seperti jalan, jembatan, listrik dan lain-lain. Sedangkan, potensi sumber daya manusia dapat berupa kuantitas maupun kualitas angkatan kerja (penduduk usia produktif yang ingin bekerja) di wilayah tersebut. Semakin banyak angkatan kerja yang berpendidikan tinggi dan memiliki kompetensi kerja di suatu wilayah maka semakin banyak juga potensi sumber daya manusia yang dimiliki wilayah tersebut. Terakhir, dan yang paling utama adalah potensi modal sosial di suatu wilayah yang sangat berperan dalam upaya pemberdayaan masyarakat miskin. Modal sosial yang berakar pada berjalannya social network akan membantu percepatan proses pemberdayaan masyarakat maupun sebagai jaring pengaman bagi penduduk miskin. Output yang diharapkan dari kegiatan pemberdayaan mustahik adalah mustahik yang mandiri, tidak mengharapkan bantuan orang lain lagi, sehingga kedepannya diharapkan mustahik tersebut bisa bertransformasi menjadi muzakki.

Untuk bantuan lembaga bimbingan belajar seminggu dua kali masuk keputran, yaitu pada hari minggu sore dan senin sore, untuk renovasi rumah dhuafa ada sekitar 10 rumah yang sudah direnovasi (dengan syarat harus rumah sendiri dan tanahnya bersertifikat), untuk bantuan dhuafa fakir ada sekitar 35 orang berusia lanjut yang setiap bulannya mendapatkan bantuan biaya hidup sebesar 400 ribu. Sedangkan untuk program pemberian modal bergulir ada sekitar 40 UKM binaan di wilayah Keputran Panjunan yang terbagi menjadi 4 kelompok koperasi dengan masingmasing kelompok koperasi beranggotakan 10 orang, nama-nama kelompok koperasi tersebut adalah Al-Mutakabir, Mumit, dan Al-Khodir.

Al-Mu'akhir, Al-

\section{Perancangan Model Pemberdayaan Pelaku UKM Berbasis Zakat Produktif}

Pemprov Jatim pada tahun 2010-2013 telah melaksanakan program Jalan Lain Menuju Kesejahteraan Rakyat (JALINKESRA). Program Jalin Kesra Bantuan RTSM dirancang sebagai program keberpihakan Gubernur Jawa Timur terhadap orang miskin (Pro Poor) yang fokusnya adalah memberikan bantuan terhadap Rumah Tangga Sangat Miskin (RTSM) berupa bantuan uang dan pangan (cash transfer) dan natura produktif.

Dalam mekanisme pelaksanaan program Jalinkesra ada beberapa kegiatan yang seharusnya dilaksanakan oleh pihak pelaksana program, yaitu

1. Pendataan (identifikasi sasaran).

2. Sosialisasi.

3. Konfirmasi Lapangan.

4. Pengadaan Bantuan.

5. Eksekusi bantuan (Penyerahan bantuan).

6. Bimbingan teknis (Pendampingan).

7. Monitoring dan Evaluasi.

Untuk mencapai output yang maksimal seharusnya kesemua kegiatan tersebut dilaksanakan, tetapi berdasarkan pengamatan penulis pada praktek di lapangan kegiatan seperti konfirmasi lapangan, bimbingan teknis, monitoring, dan evaluasi tidak pernah dilakukan sama sekali oleh pihak pelaksana program. Selain itu pembekalan moral dan spiritual berupa pemberian motivasi/semangat, faktor-faktor yang terkait dengan pemberdayaan masyarakat seperti penciptaan suasana yang kondusif, penguatan skill, perlindungan sosial, penyokongan, dan pemeliharaan juga sama sekali tidak pernah diberikan oleh pihak-pihak terkait, padahal faktor moral dan mental seseorang adalah salah satu faktor terpenting dalam upaya penanggulangan kemiskinan, karena yang dapat menolong orang miskin untuk lepas dari ketidakberdayaan adalah dirinya sendiri. Akan sia-sia jika kita memberikan bantuan kepada orang miskin tetapi dia tidak mempunyai semangat untuk berubah, motivasinya untuk mendapatkan kehidupan yang 
lebih baik juga tidak ada, kebiasaannya hanya mengharapkan belas kasihan dan bantuan dari orang lain saja. Maka dari itu faktor-faktor pendukung seperti penguatan modal sosial sangat penting diberikan kepada masyarakat miskin penerima bantuan agar mereka memiliki semangat dan motivasi untuk berubah dan berkembang.

Mekanisme pelaksanaan program Jalinkesra yang tidak sesuai dengan standard pelaksanaan proyek, dikombinasikan dengan mentalitas dan kebiasaan masyarakat miskin yang cenderung susah untuk diajak berubah dan terbiasa menggantungkan dirinya kepada orang lain maka hal itulah yang menyebabkan program Jalinkesra tidak menghasilkan output yang maksimal.

Berdasarkan hasil penelitian di Kampung Keputran Panjunan maka penulis merumuskan perancangan model pemberdayaan pelaku UKM berbasis zakat produktif dengan berdasarkan pada unsur-unsur dalam modal sosial dan pendekatan pemberdayaan yang terbentuk di lokasi penelitian, kedua unsur penunjang yang sangat penting itu seolah-olah tidak tampak dalam pelaksanaan program Jalinkesra, padahal kedua unsur tersebut sangatlah penting karena perubahan mentalitas dan filosofi hidup masyarakat miskin agar mereka mau berubah sangat dipengaruhi oleh kedua unsur tersebut. Contoh pemberdayaan masyarakat yang terdapat di Keputran Panjunan adalah contoh yang ideal dalam pemberdayaan masyarakat dalam suatu kawasan karena disana terdapat semua contoh pemberdayaan. Bagi anak-anak sekolah ada program bimbingan belajar, bagi orang tua terdapat program dhuafa fakir, bagi mereka yang rumahnya rusak dan tidak mampu memperbaikinya ada program renovasi rumah, bagi yang ingin berusaha tetapi tidak mempunyai modal ada bantuan modal bergulir dan bantuan alat kerja, serta tidak lupa ada program pembimbingan spiritual dan keagamaan bagi para mustahik dengan program Jatim takwa.

Perancangan model pemberdayaan pelaku UKM berbasis zakat produktif adalah suatu perancangan program pemanfatan dana zakat untuk mendorong para pelaku UKM agar mereka mampu memiliki usaha yang mandiri sehingga taraf kehidupannya menjadi semakin baik dan tidak mengharapkan uluran atau bantuan dari orang lain lagi, dan kedepannya diharapkan dia mampu bertransformasi menjadi Muzakki.

Fungsi pembangunan nasional yang selaras dengan tujuan program pemberdayaan ekonomi pelaku UKM berbasis zakat produktif, yaitu [11]:
1. Pertumbuhan ekonomi (economi growth).

2. Perawatan masyarakat (community care).

3. Pengembangan manusia (human development).

Meskipun tujuan program pendayagunaan zakat produktif untuk pemberdayaan ekonomi pelaku UKM memiliki keselarasan dengan fungsi pembangunan nasional, pelaksanaan pendayagunaan zakat dalam bentuk produktif untuk pemberdayaan ekonomi pelaku UKM yang dilakukan oleh BAZNAS Provinsi Jawa Timur sampai dengan saat ini belum ada sinergi dengan program pengentasan kemiskinan yang dilakukan oleh Pemprov Jatim. Mereka berjalan sendirisendiri dengan perencanaan dan programnya masing-masing, tidak ada koordinasi sama sekali, belum ada pemikiran untuk mengutamakan kepentingan dan kesejahteraan rakyat diatas kepentingan pribadi atau golongan, oleh karena itu sampai sejauh ini program-program pemberdayaan itu belum mampu menyelesaikan permasalahan kemiskinan secara menyeluruh dan tuntas.

Berdasarkan pengamatan penulis tentang segala permasalahan yang terjadi pada pelaksanaan program Jalinkesra oleh Pemerintah Provinsi Jawa Timur dan segala kelebihan serta kekurangan yang dimiliki oleh program Jatim Makmur dari BAZNAS Provinsi Jawa Timur, maka penulis menganggap perlu diadakan sinergi antara pengelolaan zakat produktif untuk pemberdayaan pelaku UKM dengan program dan kebijakan Pemprov Jatim dalam penanggulangan kemiskinan. Berikut bagan rancangan model sinergitas kegiatan pemberdayaan pelaku UKM dalam upaya penanggulangan kemiskinan antara BAZNAS Provinsi Jatim dengan Pemprov Jatim : 


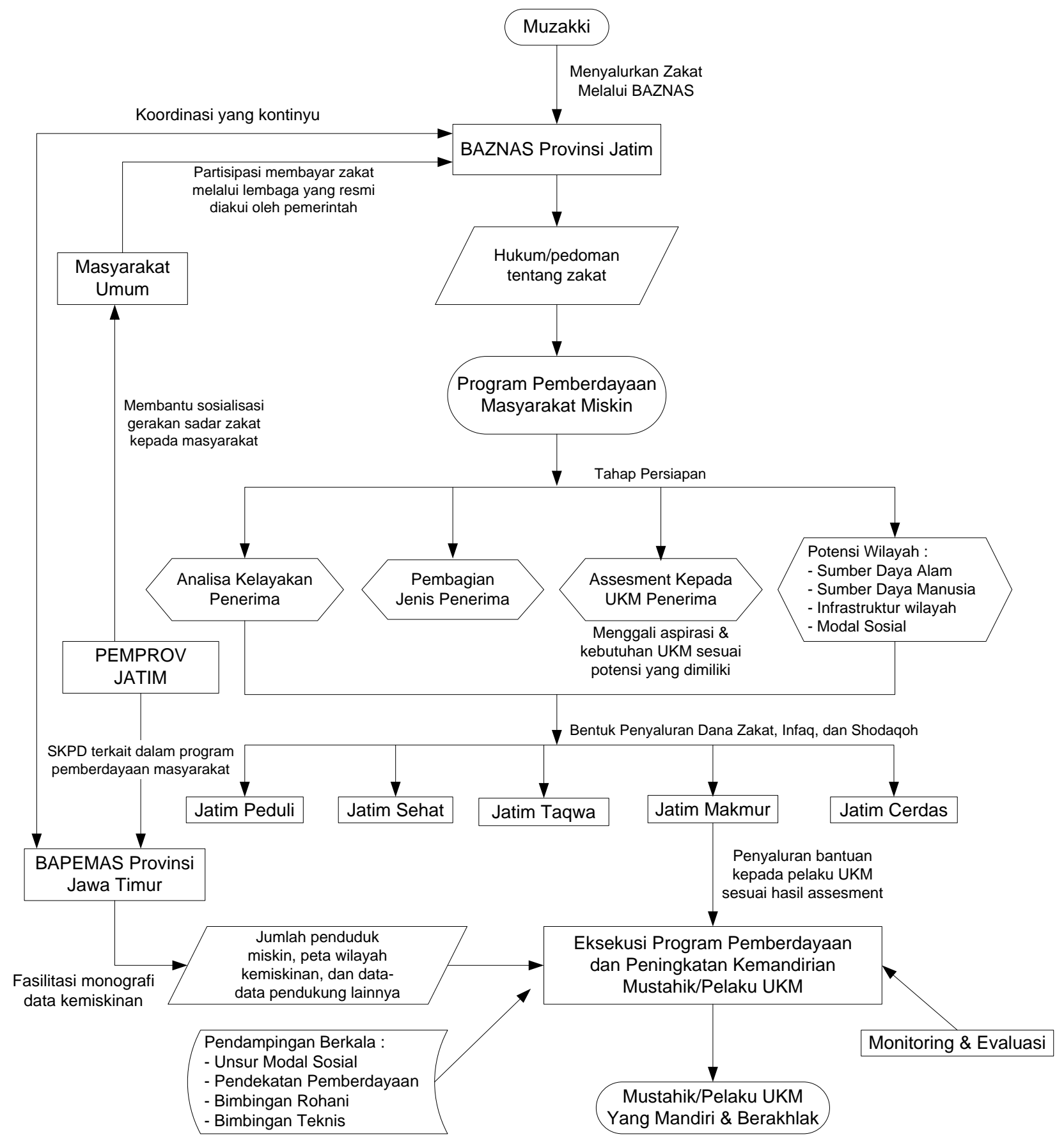

Gambar 2. Rancangan Model Sinergitas Kegiatan Pemberdayaan Pelaku UKM Antara BAZNAS

Provinsi Jatim dengan Pemprov Jatim Dalam Upaya Penanggulangan Kemiskinan di Jawa Timur

Berdasarkan gambar di atas dapat dijelaskan bahwa proses diawali dari muzakki yang menyalurkan zakatnya kepada BAZNAS Provinsi Jatim, kemudian berdasarkan hukum dan pedoman tentang zakat maka BAZNAS Provinsi Jatim melakukan tahap persiapan (preparation) untuk menyalurkan zakat yang terkumpul pada mereka kedalam program pemberdayaan masyarakat miskin. Tahap persiapan dapat diuraikan dalam kegiatan sebagai berikut :

1. Analisa Kelayakan Penerima.

Pada proses ini akan difilter secara benarbenar apakah mustahik yang bersangkutan layak menerima bantuan atau tidak, jangan sampai 
kejadian seperti program Jalinkesra terulang, dimana orang yang sebenarnya tidak layak menerima bantuan tetapi masih saja bisa menerima bantuan.

2. Pembagian Jenis Penerima.

Pada proses ini diadakan pembagian atau pengelompokan untuk penerima bantuan, apakah dia masuk kategori penerima bantuan modal bergulir atau penerima bantuan dhuafa fakir.

3. Assesment Kepada UKM Penerima.

Adalah proses penyusunan database untuk para UKM penerima yang benar-benar potensial dalam menerima bantuan, dalam proses ini akan dilihat potensi apa yang dimiliki oleh UKM penerima, dan diidentifikasi kebutuhan apa yang diperlukannya untuk menjalankan usaha, sehingga dapat ditentukan bantuan apa yang sesuai untuk masing-masing UKM penerima.

4. Pengembangan Potensi Wilayah.

Proses ini adalah faktor pendukung dalam pemberdayaan UKM penerima bantuan, yaitu pengembangan potensi wilayah dari UKM yang bersangkutan, terdiri dari sumber daya alam, sumber daya manusia, infrastruktur wilayah, dan modal sosial. Potensi sumber daya alam merupakan potensi alam yang bisa digunakan untuk meningkatkan kegiatan ekonomi dan meningkatkan pendapatan masyarakat, seperti barang tambang, hutan, minyak bumi, hasil perkebunan, pertanian, dan lain-lain. Sementara itu, potensi infrastruktur wilayah merupakan keberadaan infrastruktur dalam mendukung kegiatan ekonomi seperti jalan, jembatan, listrik dan lain-lain. Sedangkan, potensi sumber daya manusia dapat berupa kuantitas maupun kualitas angkatan kerja (penduduk usia produktif yang ingin bekerja) di wilayah tersebut. Terakhir, dan yang paling utama adalah potensi modal sosial di suatu wilayah yang sangat berperan dalam upaya pemberdayaan masyarakat miskin. Modal sosial yang berakar pada berjalannya social network akan membantu percepatan proses pemberdayaan masyarakat maupun sebagai jaring pengaman bagi penduduk miskin.

Setelah tahap persiapan selesai maka zakat, infaq, dan shodaqoh yang terkumpul disalurkan ke mustahik dalam bentuk program-program sosial pemberdayaan. Bentuk penyaluran itu melalui 5 program yang dinamakan Jatim Peduli, Jatim Sehat, Jatim Taqwa, Jatim Makmur, dan Jatim Cerdas. Khusus untuk pengelolaan zakat dalam bentuk usaha produkif melalui penyaluran modal bergulir kepada pelaku UKM dilakukan melalui program Jatim Makmur.
Melalui program Jatim Makmur lalu masuk ke tahap eksekusi program pemberdayaan dan peningkatan kemandirian pelaku UKM, disini akan disalurkan bantuan kepada para pelaku UKM sesuai dengan hasil assesment yang telah dilakukan pada tahap persiapan. Dalam penyaluran bantuan kepada pelaku UKM ini ada beberapa ketentuan yang harus dilaksanakan oleh pelaksana program, yaitu :

1. Usahanya harus jelas.

2. Usahanya harus sudah ada tetapi dia mengalami kesulitan untuk mengembangkan usahanya karena keterbatasan modal.

3. Bantuan yang diberikan adalah dalam bentuk bantuan modal bergulir dengan sistem pengembalian diangsur sebanyak $10 x$ selama 10 bulan.

4. Jika usahanya belum ada sama sekali maka bantuan yang diberikan adalah bantuan alat kerja.

5. Kalau bisa usahanya tidak boleh sama antara UKM satu dengan UKM lainnya.

6. Masuk kategori mustahik dan layak menerima bantuan.

7. Memiliki motivasi dan semangat untuk berusaha keras.

Dalam proses eksekusi program ini maka sinergitas dengan BAPEMAS Provinsi Jatim sebagai SKPD dari Pemprov Jatim yang menangani program pemberdayaan masyarakat sangat diperlukan melalui fasilitasi monografi data kemiskinan yang berupa data jumlah penduduk miskin, peta wilayah kemiskinan, dan data-data pendukung lainnya.

Tidak hanya fasilitasi monografi kemiskinan, sinergitas antara BAPEMAS Provinsi Jatim dengan BAZNAS Provinsi Jatim juga diperlukan dalam tahap pendampingan secara berkala, yang meliputi kegiatan penguatan unsur modal sosial, penguatan pendekatan pemberdayaan, pemberian bimbingan rohani dan bimbingan teknis secara kontinyu. Kegiatan pendampingan secara berkala sangat penting dan merupakan inti dari kegiatan pemberdayaan masyarakat miskin/pelaku UKM, karena tanpa pendampingan secara berkala para pelaku UKM akan sulit untuk berkomunikasi dengan pihak pelaksana program pemberdayaan, mereka tidak bisa sharing tentang permasalahan dan kendala apa saja yang dialami dalam pengembangan usahanya, hal inilah yang mengakibatkan kesulitan untuk menghasilkan output yang maksimal dalam kegiatan pemberdayaan masyarakat.

Dengan komunikasi yang intens antara pelaku UKM dengan pihak pelaksana program 
pemberdayaan masalah yang muncul bisa segera dikomunikasikan dan dicari solusinya, sehingga bantuan modal bergulir atau alat kerja yang diberikan bisa dimanfaatkan secara maksimal oleh UKM penerima bantuan. Pendampingan secara berkala inilah yang hilang atau tidak dilaksanakan dalam program Jalinkesra, hal itulah yang menyebabkan kenapa output program Jalinkesra tidak maksimal dan banyak terjadi penyimpangan.

Kegiatan pendampingan secara berkala berfungsi untuk mengeluarkan potensi terpendam yang dimiliki oleh UKM penerima bantuan, proses pendampingan harus diberikan secara kontinyu sampai si UKM penerima bantuan mampu benar-benar mandiri dan tidak membutuhkan pembinaan-pembinaan lagi. Dalam proses pendampingan tidak jarang diperlukan bantuan pihak ketiga, fungsi pihak ketiga disini yang utama yaitu sebagai tenaga pendamping dan pembinaan berkala. Karena dalam pendampingan dan pembinaan diperlukan kemampuan untuk memotivasi dan skill khusus dalam pelatihan kerja sesuai dengan bakat dan minat masing-masing orang maka diperlukan pihak ketiga yang mampu dan kompeten dalam melakukan kegiatan pendampingan dan pembinaan. Jika ada SDM yang kompeten dari dalam maka tentunya akan lebih baik karena bisa lebih menghemat biaya.

Dalam kegiatan implementasi dana zakat untuk kegiatan produktif hendaknya BAZNAS Provinsi Jatim senantiasa berkoordinasi dengan BAPEMAS Provinsi Jatim, agar kegiatan pemberdayaan yang sama-sama mereka lakukan bisa selaras, serasi, dan seimbang, jangan sampai tumpang tindih di 1 lokasi yang sama, jika dalam lokasi tersebut bisa dikerjakan bersama tentunya akan sangat baik dan saling menunjang, tetapi jika programnya harus berjalan sendiri-sendiri diharapkan saling memonitoring untuk melengkapi kekurangannya masing-masing, karena belum tentu program dari Pemprov Jatim bisa berjalan baik di satu lokasi binaan, tetapi program BAZNAS malah yang sesuai untuk daerah tersebut, begitupun juga sebaliknya.

Peran serta aktif dari Pemprov Jatim juga sangat diharapkan untuk membantu mensosialisasikan gerakan sadar zakat kepada masyarakat, hal ini berfungsi untuk memberikan pemahaman kepada masyarakat bahwa dengan berzakat selain menunaikan kewajiban bagi dirinya sendiri juga dapat membantu sesama yang membutuhkan. Sebaiknya dalam sosialisasi tersebut juga diselipkan pesan jika berzakat harus melalui lembaga yang terpercaya seperti BAZNAS
Provinsi Jatim atau LAZ-LAZ yang diakui oleh Pemerintah, tujuannya agar zakat yang dibayar oleh muzakki dapat dikelola dan disalurkan dengan tepat. Disamping itu dengan berzakat kepada lembaga zakat yang diakui dan disahkan oleh pemerintah dapat mengurangi penghasilan kena pajak (telah diatur dalam Undang-Undang No. 17 Tahun 2000 tentang Perubahan Ketiga atas UU No. 7 Tahun 1983 tentang Pajak Penghasilan), zakat dikenakan kepada penghasilan bruto lalu dikurangkan kepada penghasilan kena pajak.

Tidak kalah pentingnya dalam program penanggulangan kemiskinan harus memperhatikan unsur modal sosial dan pendekatan pemberdayaan masyarakat, karena 2 komponen tersebut adalah katalis utama dalam kegiatan pembangunan kesejahteraan masyarakat. Pentingnya modal sosial tidak hanya bagi negara-negara berkembang guna mempercepat proses pembangunan dari masyarakat yang sangat tradisional menuju masyarakat modern, tetapi juga bagi negaranegara yang telah maju. Di negara-negara maju modal sosial merupakan salah satu unsur yang sangat penting dan inheren dalam berbagai perencanaan pembangunan dan pelayanan masyarakat yang dirancang [12].

\section{KESIMPULAN}

Dalam mekanisme pengumpulan zakat ada 3 cara yang dilakukan oleh BAZNAS Provinsi Jawa Timur, cara yang pertama yaitu muzakki/donatur datang setor langsung ke BAZ atau transfer ke rekening BAZNAS Provinsi Jatim, cara yang kedua diambil petugas juru pungut (jungut) ke rumah/alamat muzakki, dan cara yang terakhir yaitu dikumpulkan melalui bendahara gaji atau UPZ (Unit Pengumpul Zakat) di masing-masing instansi kerjanya. Penyaluran dana zakat, infaq, dan shodaqoh ke dalam bentuk 5 program kegiatan, yaitu Jatim Cerdas, Jatim Peduli, Jatim Makmur, Jatim Sehat, dan Jatim Takwa.

Secara umum implikasi penyaluran zakat produktif dalam bentuk bantuan modal bergulir terhadap keadaan ekonomi pelaku UKM cukup positif, hal ini dibuktikan dengan aset mereka yang bertambah (berupa penambahan barangbarang rumah tangga dan alat-alat produksi untuk menunjang pekerjaanya), dan penghasilannya yang berubah dari tidak menentu menjadi berpenghasilan tetap.

Dalam perancangan model pemberdayaan pelaku UKM berbasis zakat produktif diperlukan sinergitas yang kontinyu antara Pemprov Jatim dengan BAZNAS Provinsi Jatim. Dalam 
implementasi program pemberdayaan masyarakat juga diperlukan koordinasi yang kontinyu agar program yang dilakukan oleh BAZNAS dan Pemprov Jatim tidak tumpang tindih di satu lokasi yang sama, kalau bisa harus saling melengkapi kekurangan masing-masing, tidak boleh berjalan sendiri-sendiri sesuai egonya masing-masing seperti selama ini.

\section{SARAN}

Pemprov Jatim bersama dengan BAZNAS Provinsi Jatim harus mendorong masyarakat untuk sadar zakat, dalam artian mereka dimotivasi agar teratur mengeluarkan zakatnya, karena dengan potensi zakat yang semakin meningkat tentunya akan banyak manfaatnya dalam upaya penanggulangan kemiskinan. Hal ini secara tidak langsung juga mendidik masyarakat untuk aktif berperan dalam upaya penanggulangan kemiskinan melalui zakat yang telah mereka keluarkan. Alangkah lebih baiknya jika dari Pemerintah mengeluarkan semacam undangundang yang sifatnya memaksa seperti pajak bahwa jika ada seorang muslim dan penghasilannya telah mencapai nisab yang telah ditentukan maka dia wajib berzakat ke Badan Amil Zakat atau Lembaga Amil Zakat yang dibentuk dan disahkan oleh Pemerintah.

\section{UCAPAN TERIMA KASIH}

Terima kasih penulis sampaikan kepada Pemerintah Provinsi Jawa Timur dan Universitas Brawijaya yang telah memberikan kesempatan kepada penulis untuk melanjutkan pendidikan program magister sosiologi kajian kemiskinan di Universtas Brawijaya. Terima kasih juga kepada segenap karyawan BAZNAS Provinsi Jawa Timur, petugas kelurahan Embong Kaliasin, dan warga kampung Keputran Panjunan atas kesediannya menjadi tempat penelitian bagi penulis dalam menyelesaikan tesis sebagai tugas akhir dari program magister sosiologi kajian kemiskinan.

\section{DAFTAR PUSTAKA}

[1].Sumodiningrat G. 1998. Membangun Perekonomian Rakyat. Pustaka Pelajar. Yogyakarta.

[2].Daeng S. 2013. Chevron Dan Exxon Kuasai Kegiatan Migas Nasional. Situs http://www.merdeka.com/uang/chevrondan-exxon-kuasai-kegiatan-migasnasional.html diakses pada 14-11-2014 pukul 10.22 WIB.
[3].Soenyono. 2012. Sosiologi Pemberdayaan Masyarakat. Jenggala Pustaka Utama. Surabaya.

[4]. BAPEMAS Provinsi Jatim. 2011. Program Jalan Lain Menuju Kesejahteraan Rakyat. Situs http://bapemas.jatimprov.go.id/index.php/jal in-kesra/358 diakses pada 24-05-2014 pukul 10.56 WIB.

[5]. Radar Online. 2013. Hampir dipastikan, Jalin Kesra JaTim 2013 di Korupsi. Situs http://radaronline.co.id/2013/09/18/hampirdipastikan-jalin-kesra-jatim-2013-di-korupsi/ diakses pada 24-05-2014 pukul 9.59 WIB.

[6].Al-Ba'ly, Al-Hamid M. 2006. Ekonomi Zakat, Raja Grafindo Persada. Jakarta.

[7].Soenyono. 2007. Memahami Penelitian Kualitatif. Jenggala Pustaka Utama. Kediri.

[8].BAZNAS Provinsi Jawa Timur. 2013. Annual Report 2013. Surabaya.

[9].Setianingrum A. 2013. "Zakat Dan Teori Irving Fisher". Situs http://any-setianingrumpasca12.web.unair.ac.id/artikel detail-85053Islamic\%20Economics\%20Management $\% 20 \%$ 20AccountingZAKAT\%20\&\%20TEORI\%20IRVING\%20FISHER.

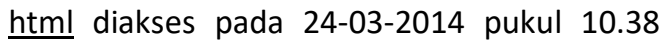
WIB.

[10]. Purwakananta A, dkk. 2010. Peta Kemiskinan, Data Mustahik, Muzakki dan Potensi Pemberdayaan Indonesia, Dompet Dhuafa. Banten.

[11]. Suharto, Edi. 2010. Membangun Masyarakat Memberdayakan Rakyat. Refika Aditama. Bandung.

[12]. Hasbullah J. 2006. Social Capital (Menuju Keunggulan Budaya Manusia Indonesia). MRUnited Press. Jakarta. 